\title{
PROSEDUR PENANGANAN RESERVASI PAKET WISATA PT. PANORAMA TOUR AND TRAVEL DENPASAR
}

\author{
Maria Melani Rosalina Hutabarat \\ I GPB. Sasrawan Mananda \\ Luh Gede Leli Kusuma Dewi \\ Email : ocha_abas@yahoo.com \\ PS. S1 Industri Perjalanan Wisata \\ Fakultas Pariwisata UNUD
}

\begin{abstract}
The travel agent plays an important to roles give all information about tourism destination to the world. Travel agents related activities which are conducted such as inbound and outbound tour, travel documents (passport/visa), ticketing, and the problem are how to handle reservation and find out about the solutions related.

Quality and quantity data resources were using as primary and secondary data. Interview and documentation were using for data analysis with descriptive analysis technic.

The procedure on how to handle package tour reservation such as: receive make a reservation of overseas agents, file the data and solution for fully booked hotel request, changes the reservations and client's complaint. Based on the reseach, the company should improve the ability of the staff for correspondence with computerized system and more staff at the airport.
\end{abstract}

\section{Keywords: Procedure, Reservation and Package Tour.}

\section{PENDAHULUAN}

Perkembangan pariwisata di Indonesia yang mempunyai potensi besar dalam kepariwisataan adalah Bali. Bali merupakan daerah wisata yang mempunyai potensi yang sangat penting sebagai daya tarik wisata. Biro perjalanan wisata sebagai penyelenggaran perjalanan wisata telah banyak membantu pemerintah dalam mempromosikan daerahdaerah tujuan wisata dan memberikan informasi mengenai situasi dan kondisi yang benar kepada calon wisatawan mengenai daerah tujuan wisata yang ada di Bali. Selain berperan dalam ikut memajukan kepariwisataan khususnya di Bali, biro perjalanan wisata juga mempunyai fungsi sebagai perantara bagi wisatawan untuk memilih paket-paket wisata yang mereka sukai selama berada di Bali. Sejak berkembangnya industri pariwisata di Bali, biro perjalanan wisata di Bali pun mengalami peningkatan. Dengan banyaknya biro perjalanan di Bali, maka jumlah pemesanan paket tour di Bali sangat meningkat tajam. Berdasarkan latar belakang tersebut maka diadakannya penelitian mengenai prosedur penanganan reservasi paket wisata PT. Panorama Tour and Travel Denpasar.

\section{TINJAUAN PUSTAKA}

Menurut Komarudin

menyebutkan bahwa "Prosedur merupakan urutan pekerjaan yang terencana dengan tujuan untuk menangani transaksi usaha yang berulang dengan cara yang beragam". Sedangkan menurut Moekijat (1997:82) "Prosedur merupakan serangkaian langkahlangkah pekerjaan tulis menulis yang berbentuk suatu cara tertentu dan dianggap baik untuk melakukan suatu keseluruhan tahap yang penting daripada kegiatan kantor". Dari pengertian-pengertian diatas dapat disimpulkan bahwa yang dimaksud dengan prosedur adalah langkah-langkah pekerjaan yang terencana dalam melakukan kegiatan perusahaan dan disusun oleh beberapa orang.

Suatu kegiatan yang akan dilakukan baik kegiatan pariwisata maupun kegiatan 
lainnya, agar dapat berhasil dengan baik membutuhkan penanganan yang baik dari pihak yang terlibat didalamnya. Dalam Kamus Besar Bahasa Indonesia (1989:897) dijelaskan bahwa "Penanganan dalah proses pembuatan, cara menangani, cara menjelaskan dan cara penggarapan". Sehubungan dengan laporan ini, yang dimaksud dengan penanganan adalah proses atau cara menangani pemesanan paket tour pada Panorama Tours and Travel.

Reservation adalah langkah awal yang dilakukan oleh wisatawan sebelum mereka melakukan perjalanan wisata di daerah tujuan wisata. Dalam Handout Tourism (1989:22) disebutkan bahwa "Pemesanan adalah komunikasi secara lisan atau tertulis untuk memperoleh kamar, tempat duduk, atau tempat untuk pelanggan sesuai dengan keinginannya". Dari uraian ini dapat disimpulkan bahwa yang dimaksud dengan reservation adalah suatu kegiatan komunikasi baik secara lisan maupun tertulis untuk memenuhi permintaan konsumen akan kebutuhan perjalanannya.

Package Tour merupakan istilah yang sering dalam dunia pariwisata, khususnya pada wisatawan yang akan datang melalui Biro Perjalanan Wisata baik itu secara perorangan atau group. Paket tour ini memberikan kemudahan dan keuntungan bagi wisatawan yang akan datang secara rombongan sebab semua komponen tour sudah termasuk dalam harga tour, dan harga tour juga lebih murah tergantung dari jumlah anggota rombongannya. Menurut Damardjati (1989:77) menyatakan bahwa "Package tour adalah sesuatu rencana atau rencana perjalanan yang sudah tersusun secara tetap dengan harga yang termasuk biaya-biaya transfer atau pengangkutan akomodasi atau hotel dan atraksi-atraksi yang tersusun dalam acara tersebut".

Menurut Foster (2000:77) "Biro Perjalanan Wisata adalah memberikan informasi tentang tingkat biaya, tarif, dan jadwal". Adapun fungsi dari Biro Perjalanan Wisata adalah sebagai perantara diantara perusahaan-perusahaan industri pariwisata di satu pihak dan wisatawan potensial di pihak lain. Dalam fungsinya sebagai pengatur tidak hanya mempertemukan wisatawan selaku konsumen dan pengusaha masing-masing perusahaan industri pariwisata, tetapi fungsi yang lebih penting adalah mempersiapkan macam-macam yang akan ditawarkan kepada wisatawan. Sedangkan fungsi dan tugas Biro Perjalanan Wisata menurut Foster (2000:78) yaitu membuat referensi, menerima pembayaran perjalanan, mengatur pengiriman tiket atau dokumen transportasi lainnya, mengatur pengeluaran tiket atau dokumen perjalanan lainnya dan mengeluarkan tiket atau dokumen perjalanan lainnya.

Menurut S. Pendit (2004 : 555) dalam glosari pariwisata kontemporer menyebutkan bahwa kata "tour" adalah perjalanan wisata dengan tujuan bersenang-senang, mengunjungi tempata yang menarrik, dsb. Dari pengertian diatas dapat disimpulkan bahwa tour and travel pada prinsipnya mempunyai makna yang sama yaitu menekankan segi perjalanan yang dilakukan seseorang dari suatu tempat ke tempat lain. Namun, sebelum wisatawan melakukan perjalanan wisatawan di destinasi yang dituju, wisatawan tersebut akan mendapatkan voucher yang diberikan oleh agen perjalanan yang digunakan. Menurut Damardjati (1987:117) menyatakan bahwa voucher adalah dokumen yang dikeluarkan oleh suatu tour operator (biro perjalanan) yang dapat ditukarkan oleh wisatawan dengan fasilitas-fasilitas akomodasi (kamar hotel), makan, darmawisata (sight-seeing), dan lain sebagainya yang akan dibayar oleh tour operator yang mengeluarkan voucher tersebut. Sebelum wisatawan mendapatkan voucher, wisatawan harus menyelesikan sendiri pembayaran terhadap fasilitas-fasilitas yang tercantum dalam voucher. Voucher biasa juga disebut coupons / exchange orders.

\section{METODE PENELITIAN \\ Lokasi Penelitian}

Penelitian ini dilakukan di Panorama Tours and Travel yang berlokasi di Jl. By Pass Ngurah Rai No. 620 Sanur, Bali Telp (0361) 726808 e-mail panorama-tours.com. Jenis data pada penelitian ini yaitu data kualitatif yang merupakan data yang tidak berupa angkaangka yang sulit diukur dan data kuantitatif yang merupakan data berupa angka-angka yang dapat dihitung.

Teknik pengumpulan data yang dilakukan dalam penelitian ini adalah teknik observasi yang dilakukan dengan melakukan pengamatan secara langsung tentang objek yang diteliti mengenai penanganan reservasi paket wisata pada Panorama Tours and Travel. Teknik wawancara mendalam yang dilakukan 
dengan cara mengadakan tanya jawab langsung dengan operation staff yang ada di perusahaan. Dokumentasi yaitu cara pengumpulan data dengan mengambil dokumen atau catatan-catatan mengenai penanganan reservasi paket wisata pada Panorama Tours and Travel. Studi Kepustakaan yaitu pengumpulan data dari literatur-literatur, laporan-laporan penelitian, dan bahan tertulis yang memiliki relevansi dengan masalah yang dikaji.

Analisis data yang digunakan adalah analisis deskriptif kualitatif yaitu data yang terkumpul baik dari hasil pengamatan langsung di lokasi penelitian (observasi) ataupun hasil dari wawancara mendalam kepada para informan yang disusun ke dalam bentuk uraian-uraian yang menggambarkan suatu keadaan, suatu proses, maupun peristiwa tertentu yang sifatnya menerangkan.

\section{HASIL DAN PEMBAHASAN \\ Gambaran Umum Perusahaan}

Perkembangan pariwisata yang sangat pesat mendorong para pemilik modal untuk membuka usaha dalam sektor pariwisata dan investor berlomba-lomba untuk menanamkan modal di sektor pariwisata seperti akomodasi, restoran dan agen perjalanan. Perkembangan pariwisata yang pesat mendorong Bapak Adhi Tirtawisata untuk mendirikan sebuah biro perjalanan 41 tahun silam, tepatnya pada tanggal 10 April 1972. Pada awalnya, Panorama Leisure hanya untuk menangani bisnis wisata domestik dan juga transportasi bus wisata untuk mendukung bisnis 'inbound'. Pada tahun 2001, Panorama Leisure direstrukturisasi menjadi sebuah Perseroan Terbatas dan disebut: PT Panorama Sentrawisata, Tbk. Perusahaan berkembang dengan pesat dan berubah menjadi badan usaha dengan 4 pilar bisnis "Inbound, Travel \& Leisure, Transportasi, dan MICE”.

Pada awal biro perjalanan berdiri hanya mempunyai 4 karyawan dan sekarang, jumlahnya sudah 3.700 karyawan dengan 20 lebih anak perusahaan. Setelah 41 tahun berkecimpung, Panorama sekarang bertransformasi menjadi kelompok terpadu, dengan 27 brand berbeda yang mencakup ruang lingkup area Destination Management, Travel \& Leisure Management, Convention \& Exhibition, transportasi dan perhotelan. Sekarang ini Panorama Group menawarkan lebih banyak produk dari manajemen pariwisata, konferensi profesional \& organizer pameran, dengan armada lebih dari 1000 bus \& taksi eksekutif, penyewaan mobil, taman rekreasi, restoran \& kafe, publikasi, pembangunan hotel, manajemen hotel dan saluran distribusi hotel. Ada anak perusahaan langsung, ada juga yang pembentukannya bersama dengan pihak lain. Contoh travel agent yang berkerjasama dengan PT. Panorama Tours and Travel adalah Panorama Tour, Travel and Ticketing Ungaran, Semarang dan contoh airlines yang bekerjasama dengan PT. Panorama Tours and Travel adalah AirAsia. Jadi salah satu anak perusahaan Panorama Tours and Travel berada di Bali berlokasi di Jl. By Pass Ngurah Rai No. 620 Sanur, Bali. PT. Panorama Tours and Travel memiliki guide yang berpengalaman. Seluruh guide yang bekerja di perusahan ini mempunyai lisensi dan training pada prosedur PT. Panorama Tours and Travel menjadi salah satu anggota dari ASITA, IATA dan PATA.

\section{Kegiatan Usaha dan Fasilitas}

PT. Panorama Tours and Travel bergerak dibidang pelayanan jasa, khususnya jasa perjalanan wisata kepada wisatawa. Adapun kegiatan usaha yang dimiliki oleh PT. Panorama Tours and Travel antara lain Reservation yang melayani reservasi terhadap fasilitas-fasilitas yang dibutuhkan oleh wisatawan, seperti akomodasi, restaurant, atraksi wisata, tour maupun yang lainya. Inbound Tour yang menangani wisatawan asing yang masuk ke dalam negeri. Transportasi yang pelaksanaan tour, transfer in dan transfer out serta kebutuhan lainnya, wisatawan akan membutuhkan alat transportasi sebagai alat angkut. PT. Panorama Tours and Travel menyediakan alat transpotasi sendiri. Alat transportasi yang dimiliki oleh PT. Panorama Tours and Travel yaitu standard car, minivan, minibus dan bus guide yang menyediakan pelayanan bagi wisatawan yang membutuhkan pramuwisata untuk memandu serta menemani wisatawan selama dalam pelaksanaan tour.

PT. Panorama Tours and Travel dalam melaksanakan aktivitasnya sehari-hari tentu memerlukan fasilitas-fasilitas untuk menunjang usahanya.Fasilitas-fasilitas yang dimiliki oleh PT. Panorama Tours and Travel adalah gedung dan lengkap dengan peralatan 
kerja bagi karyawannya, alat-alat yang mempermudah proses pemesanan yaitu telepon dan jaringan internet, komputer, facsimile, televisi dan kantin.

\section{Penanganan Reservasi Paket Wisata}

Pemesanan atau reservasi merupakan langkah awal yang dilakukan oleh wisatawan sebelum melakukan perjalanan wisata ke daerah tujuan wisata. Hal tersebut dilakukan dengan tujuan untuk mempermudah dan memperlancar segala aktivitas yang akan dilakukan selama berada di daerah tujuan wisata. Wisatawan domestik dapat melakukan pemesanan secara langsung melalui email kepada PT. Panorama Tours and Travel. Proses pemesanan paket wisata dari wisatawan sebagian besar dilakukan secara tidak langsung dan melalui agen-agen perjalanan yang ada di daerah asal wisatawan itu sendiri.

Pada penelitian yang telah dilakukan di PT. Panorama Tours and Travel banyak mendapatkan wisatawan yang berasal dari Belanda. Jumlah wisatawan yang paling banyak yaitu sebanyak 986 orang. Sedangkan untuk jumlah wisatawan yang paling sedikit berasal dari Indonesia sebanyak 105 orang. Karena dalam pelaksanaanya PT. Panorama Tours and Travel lebih banyak menangani pemesanan paket wisata melalui travel agent perjalanan di luar negeri, maka akan dijelaskan mengenai hal-hal yang dilakukan oleh reservation staff mengenai pemesanan paket wisata melalui agen perjalanan luar negeri. Adapun hal-hal yang dilakukan dalam proses reservasi paket wisata antara lain menerima pemesanan paket wisata, mempelajari dan memahami isi pemesanan paket wisata, pengisian reservation control card dan daily record, membuat pemesanan seperti pemesanan kamar hotel dan pemesanan restaurant, menjawab permintaan pemesanan kepada agen perjalanan, mengarsip data, membuat service order dan melakukan penegasan (reconfirmation).

\section{Kendala-kendala yang Dihadapi dan Cara Pemecahannya}

Adapun kendala-kendala yang sering dihadapi PT. Panorama Tours and Travel di dalam menangani pemesanan paket wisata adalah kamar hotel yang dipesan sudah penuh, perubahan pemesanan, pembatalan pemesanan dan complaint dari wisatawan.

\section{SIMPULAN DAN SARAN \\ Simpulan}

Berdasarkan hasil penelitian yang telah dilakukan tentang prosedur penanganan reservasi paket wisata pada PT. Panorama Tour and Travel Denpasar dapat disimpulkan bahwa penanganan reservasi paket wisata pada PT. Panorama Tours and Travel dilakukan oleh bagian Reservation Staff. Sehingga dalam menangani pemesanan paket wisata, PT. Panorama Tours and Travel juga mengalami berbagai kendala yaitu kamar hotel yang dipesan sudah penuh, biasanya terjadi pada high season. Cara pemecahanya adalah dengan memilih hotel lain yang setaraf dengan hotel sebelumnya, adanya perubahan terhadap pemesanan, cara pemecahannya yaitu dengan menginformasikan kepada pihak-pihak yang terkait atas perubahan pemesanan tersebut, adanya perubahan terhadap pemesanan, cara pemecahannya yaitu dengan menginformasikan kepada pihak hotel dan pihak lainnya yang terkait atas pembatalan pemesanan tersebut dan adanya keluhan dari wisatawan mengenai kondisi hotel yang telah dipesan, pemecahanya adalah dengan menawarkan hotel lain yang sesuai dengan keinginan wisatawan.

\section{Saran}

Pada penelitian yang telah dilakukan tentang prosedur penanganan paket wisata PT. Panorama Tour and Travel Denpasar dapat disarankan untuk meningkatkan pelayanan dan profesionalisme kerja terhadap wisatawan di masa-masa yang akan datang. Sehingga staff yang berhubungan langsung dengan wisatawan dapat menambah pengetahuan dan kemampuan dalam memberikan pelayanan yang lebih baik. Untuk menambah tingkat volume penjualan pada perusahaan, maka disarankan agar diadakan kegiatan outbound tour dan tidak hanya mengandalkan dari kegiatan inbound tour.

\section{DAFTAR PUSTAKA}

Departemen Pendidikan dan Kebudayaan 2000 Kamus Besar Bahasa Indonesia. Balai Pustaka. Jakarta.

Damardjati, R.S 1989, Istilah-istilah Dunia Pariwisata,Jakarta: Pradnya Paramitha

Dennis L. Foster. 2000. Introduction to Travel and Tourism, Jakarta: Raja Grafindo Persada 
Jurnal IPTA

Vol. 2 No. 2, 2014

Komaruddin, (1989), Ensiklopedia Manajemen, Jakarta: Bumi Askara

Moekidjat, Drs, 1997. Managemen Pemasaran,Jakarta: PT. Gramedia Pustaka Utama

Paramarta. 2005. Strategi Penanganan Operasional Dynasty Package Tour pada PT. Anta Express Tours and Travel. Denpasar, Bali.
PT. Panorama Tours and Travel. 2013.Jl. By Pass NgurahRai No. 620 Sanur, Bali.

S. Pendit, Nyoman. 2005. Glosari Pariwisata Kontemporer, Jakarta: Pradnya Paramita Yusma, Luana. 2001. Pengaruh Penanganan Pemesanan Kamar (Reservation) melalui Travel Agent terhadap Tingkat Hunian Kamar Hotel Kuta Paradiso. Kuta, Bali. 